$\underline{\text { Video Essay }}$

\title{
What Does (a Nasty) Woman Want?
}

\author{
Agnieszka Piotrowska ${ }^{1 *}$
}

Published: September 8, 2020

\begin{abstract}
In this video essay I have juxtaposed material from three films about female desire - made by women at different historical moments in time, in different countries. These are: The Piano (1993) by Jane Campion, Fuga (2018) by Agnieszka Smoczynska and Portrait of a Lady on Fire (2019) by Celine Sciamma. In the Polish context it is particularly important that these three films about female desire speak to each other, as Poland has been late in acknowledging its links to international feminism. The video essay and the text which accompanies it also evoke the recent Polish Nobel Prize Winner for Literature Olga Tokarczuk and Wislowa Szymborska, the Polish poet who also won the Nobel Prize in 1996. In terms of the films, it is the figure of Alicja, in Agnieszka Smoczynska's film, who is the most radical of the three, despite Poland being the most conservative of the countries that produced the films.
\end{abstract}

Keywords: Polish cinema, feminism, Agnieszka Smoczynska, female desire

As film historian and theorist Pam Cook has noted, in relation to her own practical exploration of videographic practice in film and television studies, an audiovisual video essay can produce a 'writerly' experience à la Roland Barthes in which viewers / readers / essayists generate their own meanings: 'the video essay constitutes an event; it transforms existing material to fashion an open-ended process of re-reading and re-writing' (Cook, 2014). Catherine Grant (2013 and 2018), the main proponent of the video essay in recent times, sees it as a tool of exploring what visual intertextuality can produce in terms of new knowledge. This short article aims to accompany the film work, clarifying some points, but not proposing a fully-fledged research argument. Rather, like the video essay itself it hopes to invite the reader to undertake further explorations for herself.

In the video essay I have juxtaposed material from three films about female desire that have been made by women at different historical moments in time, in different countries. These are: The Piano (1993) by Jane Campion, Fuga (2018) by Agnieszka Smoczynska and Portrait of a Lady on Fire (2019) by Celine Sciamma. We begin the video essay almost jokingly with Sigmund Freud's famous quote from his letter to Marie Bonaparte in which he despairs that it is impossible to know the nature of female desire (cited in Jones, 1953: 421). In the Polish context it is particularly important that these three films about female desire speak to each other, as Poland has been late in acknowledging its links to international feminism. In contextualising my video essay I remember Donna Haraway's writings about 'situated knowledges', (1988: 581) particularly regarding her call for challenging the 'objectivity' of patriarchal knowledge claims and how this might relate to female authorship. Haraway argues for the

politics and epistemologies of location, positioning, and situating, where partiality and not universality is the condition of being heard to make rational knowledge claims. These are claims on people's lives. I am arguing for the view from a body, always a complex, contradictory, structuring, and structured body, versus the view from above, from nowhere, from simplicity. (589)

The Piano occupies a special place in feminist film studies scholarship as it re-introduced bodily responses to films studies scholarship (Sobchack, 1991). It is this intertextual bodily approach which I have used in the construction of this video essay. It prioritises the female body, through tracing the parallels of the works. Fuga constitutes a deeply feminist gesture and yet both the director Agnieszka Smoczynska and the screenwriter Gabriela Muskala, who also plays Alicja, are reluctant to use the word 'feminism' in their interviews. According to 
Smoczynska (Danilewicz, 2019) the film is about finding freedom (or translating her words differently, about liberating oneself although in that interview too she does not use the word 'feminism'.

Yet, despite the reluctance of using the term, out of these three films I argue it is the Polish film that offers the most radical feminist gesture: the main character leaves the traditional structures twice despite being a mother and a wife. This is in a country which still heralds the importance of the values of the Roman Catholic Church, religion and tradition which in its turn translates itself in continuous subjugations of women and women's bodies in everyday life, including the numerous attempts to abolish abortion and declaring gay relationships as 'suspect'. Poland is the only country in Europe which does not recognise gay marriages and has 'LGBT free' areas which is an illegal gesture under European law and yet Poland is a part of the EU. The recent re-election of the conservative President, Andrzej Duda emphasises the conservative nature of the country, although the fact that almost $50 \%$ of the population of Poland voted for the more liberal candidature of Rafal Trzaskowski offers some hope.

In the video essay we have tried to draw clear visual parallels between the three films, in which the main characters struggle with the various constraints of the system of social patriarchy, yet despite this, they attempt to explore their own bodies and their own desire. In all three cinematic texts the characters are presented with choices pertaining to their creativity and their sexuality: their relationship to their bodies and their struggles with their desire vis à vis familial duties. The video essay maps the movement of the characters, the desire for closeness, the sequences including attitudes to motherhood, as well as the classic metaphors evoking a sense of freedom and sexuality such as open sea, waves, and the water threatening to engulf the characters. In some way ways one could argue that the characters' attempts are transgressive but that in the narratives of the films, two out of three women stay within patriarchal constraints. Alicja, the protagonist of Fuga (2018), both undermines the structures she finds herself in, and also finally leaves again when she understands that it is not possible to change the system, or her situation, from within.

This work builds on my research on the Nasty Woman in cinema (2019). I see the figure of the nasty woman as a possible gesture of resistance to patriarchal structures. In my book I looked at the figure of the nasty woman in English speaking cinema. The new research project begins to analyse unpleasant and unconventional female characters in international cinema. In my book I developed Sara Ahmed's idea from her work entitled Living a Feminist Life (2017: 38) in which she names the 'feminist killjoy', a woman who disrupts stable situations and norms, if necessary at a high cost to herself, and to others. Alicja in Fuga is just such a 'killjoy': she speaks her mind, she refuses to obey convention, she takes charge of her body (the body which becomes different and more powerful on her return), she is sexually more open and liberated. She loves her family but she is a different person now whom, in order to break the normative requirement of being a 'nice mother and wife', chooses to physically leave her surroundings, and in order to do so she has to lose her memory and, seemingly, her sanity. Alicja can be perceived as deeply destructive in her creative re-imagining of her life but the viewer can also instead interpret her decisions and her state of mind as drawing from other traditions of nasty women who deployed madness in order to resist patriarchy.

Culturally, in world literature, there are stories and indeed operas in which the nasty and sexually unconventional woman moves away from her position of some power over men (be it through her sexuality) to a position of sacrifice and a necessary death in order to atone for her nastiness. In Poland it is very recent that the controversial and maligned Polish feminist writer Olga Tokarczuk has won international acclaim, including the Booker Prize (2018) and then the Nobel Prize for Literature (2019); both of these awards were endowed to the author to the Polish conservative government's incredulous dismay. In her work Tokarczuk advocates non-traditional models of femininity, indeed she is perceived as a subversive person in the conservative Poland. ${ }^{1}$ Her female characters are often on the peripheries of society, often on the brink of mental illness, indeed either on a physical journey (Flights), or prepared to take one (Drive Your Plow Over the Bones of the Dead) when the systems she finds herself in call her to take dramatic and controversial actions. This approach is exceptional. In Europe there are many examples of rather insane nasty woman who end badly. There is the famous and influential novella by Alexandre Dumas The Lady of Camelias (La Dame aux Camélias) (1848), made into numerous theatre adaptations and then the famous opera by Verdi, La Traviata (1852) which was also the subject of multiple film and television adaptations. The public appetite for a tale of a fallen woman who somehow goes mad (but still must be punished) is quite remarkable. Puccini's La Bohéme has a nasty fallen woman too who is redeemed in her sacrifice for the man she loves. The death of the woman, nasty and tainted despite her newly attained purity, is obviously a necessary quality of this work. This trope was very popular in early cinema too, in films starring Pola Negri, such as Mania (1918), Madam Du Barry (1919), Das Martyrium (1921) and others. Another fantasy of a nasty woman who tries to defy the patriarchal order only to be killed by a betrayed lover is George Bizet's Carmen (1875) (based on a story of the same name written by Prosper Mérimée, which indeed became one of Pola Negri's great roles in 1920). We love Carmen stating boldly to Don José, who at this point is her husband and not just a lover any more: "I don't want to be

\footnotetext{
${ }^{1}$ In the UK, from where I am writing, we now have translations of her two novels Flights (2018) which won the Booker Prize
} and also the controversial eco thriller Drive Your Plow Over the Bones of the Dead (2011 [2018]). 
harassed and above all I don't want anyone telling me what to do. I want to be free and do what I like" (Mérimée, 1980: 95). But, it is very clear that her (sexual) freedom cannot last and her way of living is doomed. Don José begs her to give it up but she, Antigone-like, refuses and so has to die: the audience concludes that nastiness does not pay in the patriarchal world.

In Fuga the main character Alicja loses her memory, is returned to her family, and then consciously leaves again. She is not punished. She sets out on a new journey - alone. Tokarczuk's characters do their own thing too, often stubbornly refusing to comply with the Church's rulings. Through that they are often in direct opposition to the conservative government.

Visually, there are similarities and parallels between the three films but, again, one could argue that Alicja provides the biggest challenge in terms of her on-screen looks and personal. It is beyond the scope of this brief essay to explore the implications of the female beauty and the demands put on the filmmakers to produce good looking female characters who would appeal to a male gaze. I evoke here Laura Mulvey's classic 1975 essay on Visual Pleasures which stresses how the iconography often relates to hidden messages of the cinematic work, conventionally a pretty passive woman versus an active strong man. Rosalind Galt more recently (2011) explores and challenges some of the ideas of female prettiness in her work, identifying the persistent pattern of female beauty in cinema and its feminist criticism as problematic in itself as female beauty has traditionally been a way of female empowerment too. It is important to point out how out of the characters in the three films, it is Alicja again who refuses to be 'pretty'. In the film, there are some suggestions of her persona from the past, in which she clearly conformed to the expected standards of traditional beauty.

When she returns, she looks almost androgynous, with her newly muscular body and short spiky her. Through the sex scenes between Alicja and her husband (some of which we have included in our video essay) Smoczynka seems to suggest that the traditional version of prettiness and passivity is not necessarily something a man wants either. There is thus a sense of a mutual entrapment in Fuga, the traditional binary being an outmoded model, which nobody wants or needs but which still persists. It is important to note, even in passing, that the visual filmic language of The Piano and Portrait of Lady on Fire echoes each other, in their elegance and beauty, perhaps in part at least because the two films offer a period look at the femininity. The main characters of the two films are also artists which is important. Whilst Ada's piano playing is the only way she is able to express herself, her seduction by Baines is connected to him making her creativity a transaction (he lets her play the piano, and she lets him undress her). In Sciamma's film, the mother of the young girl (Heloise) is the client. She pays Marianne, the painter, making sure the power relationships are never forgotten. There is an element of deception too in the encounter between Heloise and Marianne as the latter does not reveal to Heloise that she is in fact painting her until much later in the narrative. Sciamma though gives her artist more agency and the visual clues for those who have seen the two films are clear. At the very end of the film, Ada has mixed feelings about her future and the piano almost pulls her to her death as it accidently falls into the ocean. Ada cuts the rope and frees herself but there is a sense of uncomfortable foreboding in the ending despite the domestic scenes at the very end.

Conversely, Marianne's painting materials which accidentally fall into the ocean at the beginning of the film are rescued by Marianne herself: it is her craft and her way of being independent, be it in a limited way. Her love and sexual desire for Heloise do not define her. She can and does survive her broken heart. In Smoczynska's Fuga the visual language of the film is starker and its colour scheme is less rich than in the two other films under discussion here. Alicja is no artist, her creative project is her life but even expressing it this way makes it somehow romantic and there is nothing romantic in Alicja's undertaking - to reinvent herself in ways which are even selfish but necessary. Her determination is resolute and in some ways unpleasant, yes, nasty. This is the Antigone like 'monstrous' determination which I have written about elsewhere (Piotrowska, 2014; 2019). Alicja's decisions about how she performs herself resonate with Butler's foundational notions of gender as a performance (1990). Alicja's new 'performance' as a tougher version of herself finds its expression also in Smoczynska's austere direction and the production design and cinematography which remain a certain sense of austerity, despite occasional beauty of the beach scenes.

If there is a sense of pleasant satisfaction in the endings of in The Piano and in The Portrait which in some way corresponds to our cultural desire, not to say a demand, for a happy ending (discussed by Sarah Ahmed in The Promise of Happiness (2010), or Lauren Berlant in Cruel Optimism (2011)) then Fuga again does not deliver that at all. As a formal experiment, I wanted to offer a suggestion of a happy ending through a re-writing of what the final scene of the film might mean. My narration over the last shot of our video essay which is also the last shot of Fuga re-writes the sense of anxious and lonely determination of Smoczynka's ending by combining it with some uplifting ideas about freedom from Sciamma. One could critique Sciamma's moments of sentimental seduction of the film by the beauty of the landscapes she presents through the exquisite cinematography and the beauty of her main characters. As mentioned previously, there are issues with the freedom achieved by the female protagonists of the movie. Marianne, the painter, manages a semi-independent life as an artist only because we are told that she was running her father's workshop. Heloise gets married after all despite her passionate attachment to Marianne. The 
film's beauty in some way makes the compromise of the film more acceptable and could be seen as the film's flaw. I resist this critique and let myself be seduced by the aesthetic of the film which allows for the notion that art can in some ways compensate for the disappointments of life.

If I were to discuss the viewer's reactions to the films in terms of haptic film theories (Sobchack, 1991; Marks, 2000), then clearly Fuga creates the sense of greatest visceral upset on the part of the viewer and an actual embodied sense of abandonment which contrasts with a quiet hope of the other two films. The nastiness of Alicja is in part alienating also because of the issue of motherhood which I can only touch upon here, and which in the video essay too is only signaled gently. Ada in The Piano has moments of 'forgetting' her duties as a mother because of her passion for Baines but ultimately still is faithful to her role as a mother. One of the themes of The Portrait is motherhood, the responsibility of it, the choice to be a mother (or not), the possible joy of motherhood which might compensate for the sacrifices of living in the patriarchal. Here too Alicja's character offers the most radical and most brutal gesture as she leaves her little boy even as he pleads with her to stay.

In the video essay we wanted to include the voices of the two Polish Nobel Prize winners for literature: the aforementioned Olga Tokarczuk as well as the poet Wislawa Szymborska ${ }^{2}$ whose poem Portrait of $a$ Woman offers an ironic commentary on societal expectation regarding the position of woman in society. In her privileging of uncertainty she is a feminist although, again, she is reluctant to define herself as such.

At the end of the video essay, over the aerial shot of Alicja leaving, I evoke the final words of Sciamma's work 'non possum fugere' which means 'it is not possible to fly', although Sciamma insists in her film it means exactly the opposite, namely that those who cannot fly, cannot understand those who do. Without making things too obvious, we wanted to signal how the defiant gesture of Alicja in Smoczynska's film corresponds to the fight for freedom of the Polish women. We used documentary news footage of recent female protests in Poland, the device of the split screen to suggest the multitude of the resistance. It is telling that Alicja in Smoczynska's film causes difficulties in Polish reactions too, even those especially designed to be feminist. In a special edition of an open access journal of the Polish Institute of Film Arts published in November 2019, Smoczynska's work is mentioned only in passing, without any analysis (Akademia Polskiego Filmu, 2019). Instead, there is a discussion of the need to fund the cinema created by women which of course is crucial but the representation of women as being able to be quite nasty is still some way away from Polish screens, and in fact it is Tokarczuk, the writer and not a filmmaker, who could be seen as a most radical female artist today in Poland.

A video essay by definition ought to work as a piece of creative work in its own right. I believe ideas in it should be suggested and not always spelled out. In this approach, the method echoes Tokarczuk's controversial disclaimers in Flights. Sensationally and provocatively, she believes that the translation between experience and language fails. In the English paperback of the novel Flights which is over 420 pages long, the author questions the whole project of actually 'describing' things through language. She says the following:

Describing something is like using it ${ }^{3}$ - it destroys; the colours wear off, the corners lose their definition, and in the end what's been described begins to fade, to disappear. (Tokarczuk, 2018: 75).

Tokarczuk's narrator then goes on to confess that she too 'in her youthful naïveté, once took a shot at the description of places' (75) but discovered soon enough that they never worked, that they always betrayed the experience. She bemoans: 'The truth is terrible: describing is destroying', and then elaborates: 'Which is why you have to be careful. It's better not to use names: avoid, conceal, take great caution in giving our addresses, so as not to encourage anyone to make their own pilgrimage. After all, what would they find there? A dead place, dust, like the dried-out core of an apple' (75).

The reference to the apple might be significant in so far as in Christian and western cultures it is forever associated with the lost Garden of Eden, with Eve of course succumbing to the temptation of the apple, to the temptation of (sexual) freedom and knowledge, in return for a loss of some easy innocence. In the video essay we have included a scene in which Alicja is seen to be making a raft with her son, with the apple separating them - a symbolic reference perhaps to the choices a woman needs to make, just as the primal choice of Eve.

Some of the ideas suggested in this short article as well as the video essay might need a further exploration. Working closely with my long time collaborator Anna Dobrowodzka, I have tried to evoke and encourage the writerly experience in the viewer (Cook, 2014) without naming everything there is to name. It is a creative and fluid invitation for a further exploration - of female authorship in general and the female authorship and feminism in Poland in particular.

\footnotetext{
${ }^{2}$ See https://www.poetryfoundation.org/poets/wisaawa-szymborska for more information about her

3 'Using it up' might be better? 


\section{ACKNOWLEDGEMENT}

I am grateful to my film editor Anna Dobrowodzka for her creative input to the essay and her unswerving enthusiasm for my ideas.

\section{REFERENCES}

Ahmed, S. (2010). The Promise of Happiness. Durham: Duke University Press.

Ahmed, S. (2017). Living a Feminist Life. Durham: Duke University Press.

Akademia Polskiego Filmu. (2019). http://akademiapolskiegofilmu.pl/pl/historia-polskiego-filmu/pleograf/ polskie-kino-kobiet/18 (Accessed 5 August 2020).

Berlant, L. (2011). Cruel Optimism. Durham: Duke University Press.

Butler, J. (1990). Gender Trouble: Feminism and the subversion of identity. London and New York: Routledge.

Cook, P. (2014). Word vs. image: Making Mildred's Kiss (2013), The Audiovisual Essay: Practice and theory of videographicfilm and moving image studies. https://reframe.sussex.ac.uk/audiovisualessay/reflections/ intransition-1-3/pam-cook/. (Accessed 5 August 2020).

Danilewicz, I. (2019). 'Fuga' w Cinema Lumiere. Wywiad w Agnieszką Smoczyńską, reżyser filmu. https://www.niebywalesuwalki.pl/2019/01/wygraj-bilety-na-fuge-wywiad-z-agnieszka-smoczynska-rezyserfilmu/. (Accessed 5 August 2020).

Galt, R. (2011). Pretty: Film and the decorative image. New York: Columbia University Press.

Grant, C. (2013). Deja Viewing?: Videographic experiments in intertextual film studies, Mediascape: UCLA's Journal of Cinema and Media Studies.

Grant, C. (2018). Screen Memories: A video essay on Smultronstället/Wild Strawberries, Cinergie - Il Cinema e le altre Arti. https://cinergie.unibo.it/article/view/7914/8116. (Accessed 5 August 2020)

Haraway, D. (1988). Situated knowledges: The science question in feminism and the privilege of partial perspective, Feminist Studies, 14(3), 575-99.

Jones, E. (1953). Sigmund Freud: Life and work. London: Basic Books.

Kostkowska, J. (2004). 'To persistently not know something important': Feminist science and the poetry of Wislawa Szymborska in Feminist Theory, 5(2). https:/ /www.poetryfoundation.org/poets/wisaawa-szymborska. (Accessed 5 August 2020).

Marks, L. U. (2000). The Skin of the Film. Intercultural cinema, embodiment and the senses. Durham: Duke University Press. Mulvey, L. (2009 [1975]). Visual and Other Pleasures. London and New York: Palgrave Macmillan.

Piotrowska, A. (2014). Psychoanalysis and Ethics in Documentary Film. London and New York: Routledge

Piotrowska, A. (2019). The Nasty Woman and the Neo Femme Fatale in Contemporary Cinema. London and New York: Routledge.

Sobchack, V. (1992). The Address of the Eye: A phenomenology of film. Princeton, N.J.: Princeton University Press.

Tokarczuk, O. (2017 [2007]). Flights. Translated by Jennifer Crofts. London: Fitzcarraldo Editions.

Tokarczuk, O. (2018 [2011]). Drive Your Plow Over the Bones of the Dead. London: Fitzcarraldo Editions.

Citation: Piotrowska, A. (2020). What Does (a Nasty) Woman Want?. Feminist Encounters: A Journal of Critical Studies in Culture and Politics, 4(2), 33. https://doi.org/10.20897/femenc/8521

Copyright (C) 2020 by Author/s and Licensed by Lectito BV, Netherlands. This is an open access article distributed under the Creative Commons Attribution License which permits unrestricted use, distribution, and reproduction in any medium, provided the original work is properly cited. 